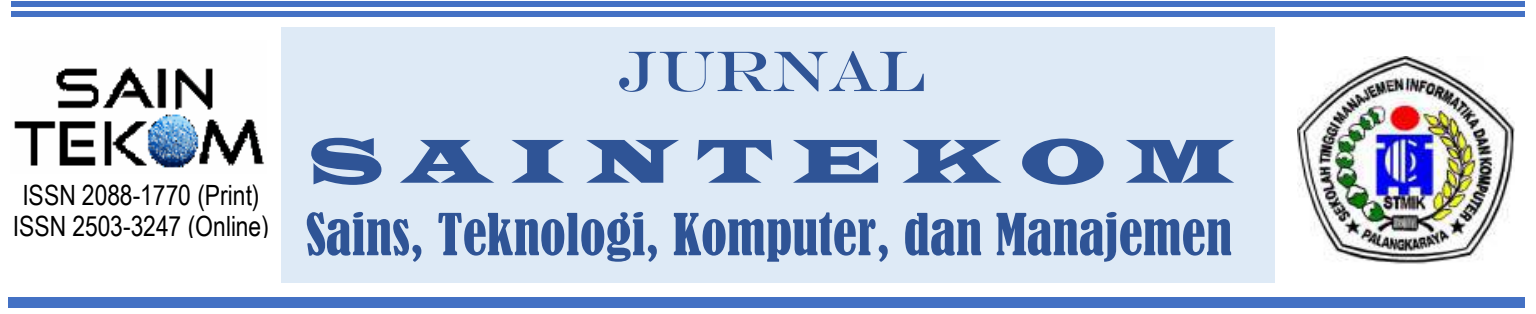

\title{
MEDIA PEMBELAJARAN INTERAKTIF UNTUK ANAK SEKOLAH MINGGU PADA GKE SINTA PARARAPAK
}

\author{
Rosalia Dwinanti $^{1}$, Bayu Pratama Nugroho ${ }^{2}$, Susi Hendartie ${ }^{3}$ \\ 1,2,3) Sistem Informasi STMIK Palangkaraya \\ Jalan G. Obos No. 114 Palangka Raya \\ Email: dwinantirosalia03@gmail.com, bayupratamanugroho@yahoo.com, \\ susihendartie@gmail.com
}

\begin{abstract}
Sunday School is an activity to teach children the basics of Christianity by delivering material according to the contents of the Bible, including the introduction of Christian songs that are packaged in a simple manner so that they are easy to understand. However, in learning activities, the teacher's way of conveying messages in the Bible is by telling stories. The learning process is conventional and has limited teaching aids and takes a long time to convey the material. In this study, the method of collecting observation data, interviews, references, documentation and questionnaires was used, while the system development method used MDLC, and the design used UML. The final result of this research is interactive learning media for Sunday school children that can be used by children for Christian religious activities. Based on the results of the user response to interactive learning media for Sunday school children by $80.4 \%$.
\end{abstract}

Keywords: learning Media, Interactive, Sunday school children, MDLC, UML.

\begin{abstract}
ABSTRAK
Sekolah Minggu adalah kegiatan mengajarkan kepada anak-anak dasar-dasar kekristenan dengan menyampaikan materi sesuai isi Alkitab, termasuk pengenalan lagu-lagu kristen yang dikemas secara sederhana sehingga mudah dipahami. Namun, dalam kegiatan pembelajaran, cara guru menyampaikan pesan dalam Alkitab adalah dengan bercerita. Proses pembelajaran bersifat konvensional dan memiliki alat peraga yang terbatas serta membutuhkan waktu yang lama untuk menyampaikan materi. Dalam penelitian ini digunakan metode pengumpulan data observasi, wawancara, referensi, dokumentasi dan angket, sedangkan metode pengembangan sistem menggunakan MDLC, dan perancangan menggunakan UML. Hasil akhir dari penelitian ini adalah media pembelajaran interaktif untuk anak sekolah minggu yang dapat digunakan oleh anak-anak untuk kegiatan keagamaan kristen. Berdasarkan hasil respon pengguna media pembelajaran interaktif untuk anak sekolah minggu sebesar $80,4 \%$.
\end{abstract}

Kata kunci : Media pembelajaran, Interaktif, anak sekolah minggu, MDLC, UML. 


\section{PENDAHULUAN}

Sekolah Minggu merupakan kegiatan pendampingan iman anak yang biasanya diadakan pada hari Minggu, inti dari kegiatan ini adalah mengajarkan dasar tentang agama Kristen kepada anak - anak Sekolah Minggu dengan penyampaian materi tentang agama Kristen sesuai isi dari Alkitab termasuk pengenalan lagu-lagu Rohani Kristen yang dikemas sederhana sehingga mudah dipahami (Nora, 2018). Di dalam Sekolah Minggu diperlukan guru pembimbing atau pengajar yang melibatkan remaja atau pemuda gereja bahkan sampai orang tua bisa ikut berperan serta menjadi guru pembimbing Sekolah Minggu (Riniwati, 2020).

Gereja Kalimantan Evangelis Sinta Pararapak memiliki sebuah wadah untuk anak yang dinamakan dengan Sekolah Minggu. Murid Sekolah Minggu terdiri dari anak - anak usia 411 tahun (Denissa, 2018). Penggolongan kelas mengajar dalam Sekolah Minggu sendiri bisa disesuaikan sesuai kelas seperti di sekolah pada umumnya atau bisa dijadikan satu menurut umur anak (Anamara, 2014). Dalam kegiatan belajar mengajar di Sekolah Minggu, cara pengajar menyampaikan pesan dalam Alkitab adalah dengan bercerita (Darmawan, 2015). Proses belajar konvensional dan keterbatasan alat peraga dan memakan waktu lama untuk penyampaian materi, hal ini tidak jarang anak Sekolah Minggu mengalami kebosanan sehingga tidak terlalu fokus dengan guru yang sedang menyampaikan materi didepan, dan anak-anak sibuk bermain dan berbicara dengan temannya (Mamangkey, et al, 2013).

Berdasarkan latar belakang masalah tersebut untuk membantu dalam proses pembelajaran agama Kristen, perlu adanya suatu media pembelajaran interaktif yang berbentuk visual (Mustika et. al, 2017) yang mampu mendukung dalam pembelajaran agama Kristen.

\section{METODE}

Metode pengernbangan yang digunakan dalam media pembelajaran interaktif ini adalah pendekatan MDLC (Multimedia Development Life Cycle) (Pressman, 2015). Tahapannya yaitu:

a. Konsep (Concept)

Pada tahap konsep antara lain: 
1) Aplikasi pembuatan media pembelajaran ini menggunakan Microsoft Powerpoint 2010.

2) Tujuan pembuatan, yaitu untuk mempermudah pembelajaran agama Kristen untuk anak sekolah minggu agar dapat mengingat, memahami materi pelajaran dan fokus terhadap materi yang disampaikan.

3) Alat bantu analisis untuk mengidentifikasi dan memberikan solusi terhadap masalah yang ada dengan menggunakan 4 (empat) aspek sebagai pembanding yaitu; Identifi, Understand, Analyze dan Report (Abdillah \& Jogiyanto, 2015).

a) Identify, yaitu mengidentifikasi masalah, berdasarkan penelitian dan pengamatan pada objek penelitian ditemukan bahwa anak sekolah minggu GKE Sinta Pararapak belum menerapkan cara pembelajaran menggunakan alat bantu.

b) Understand, yaitu memahami kerja dari sistem yang ada. Berdasarkan penelitian dan pengamatan pada objek penelitian kinerja sistem lama pada sekolah minggu GKE Sinta Pararapak proses pembelajaran masih secara biasa dengan menggunakan buku cerita dan bahkan anak-anak ada yang tidak fokus atau sibuk bermain dan berbicara dengan temannya sehingga anakanak tidak cepat memahami bahkan mengingat.

c) Analyze, yaitu menganalisis sistem berdasarkan penelitian pengamatan pada objek penelitian, sistem yang diperlukan anak sekolah minggu GKE Sinta Pararapak dalam melakukan pembelajaran serta memudahkan anak-anak untuk lebih cepat memahami pelajaran.

d) Report, yaitu setelah proses analisis sistem ini selesai dilakukan, maka penulis membuat laporan sistem.

b. Desain (Design)

Pada tahap desain menggunakan UML (Uniefied 
Modelling Language) terdiri atas

Usecase Diagram, Activity

Diagram, dan Sequence Diagram.

1) Usecase Diagram

User memulai program kemudian muncul halaman utama. Pada halaman utama terdapat pilihan menu materi, lagu-lagu sekolah minggu, Cerita Alkitab, dan Game Puzzle seperti pada gambar 1 .

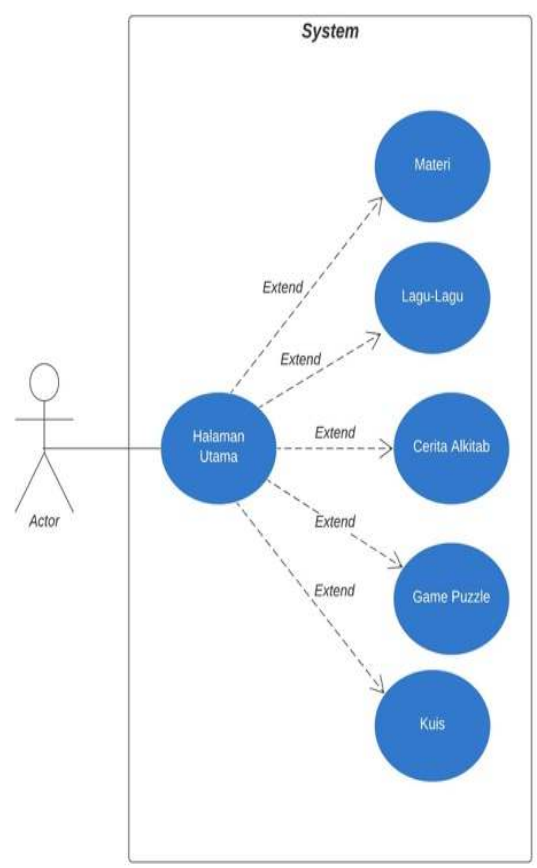

Gambar 1. Usecase Diagram Aplikasi

2) Activity Diagram

a) Activity Diagram Halaman Utama

User membuka aplikasi

kemudian muncul halaman utama. Pada halaman utama pengguna memilih salah satu halaman yang akan dibuka setelah itu sistem akan menampilkan halaman yang dipilih oleh pengguna, seperti pada gambar 2.

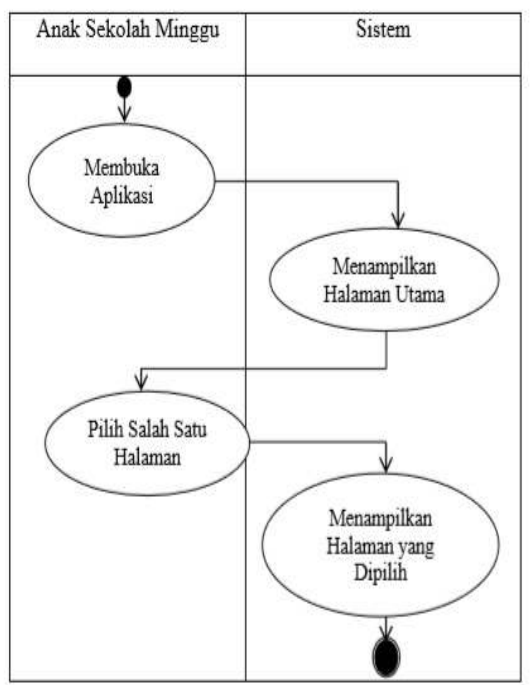

Gambar 2. Activity Diagram Halaman Utama

b) Activity Diagram Halaman Materi

User memilih halaman materi kemudian sistem menampilkan materi pada bulan juni. Pada halaman materi bulan juni pengguna memilih salah satu halaman setelah itu sistem akan menampilkan materi maka pengguna mempelajari materi yang terdapat pada sistem, seperti pada gambar 3 . 


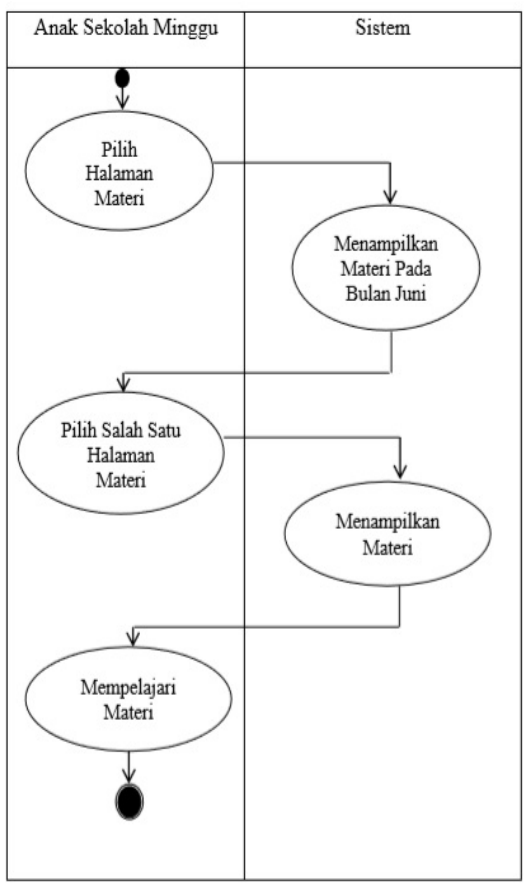

Gambar 3. Activity Diagram Halaman Materi

c) Activity Diagram Kuis

User memilih tombol kuis, tombol kuis ini terdapat pada halaman materi setelah pengguna mempelajari materi kemudian sistem menampilkan tombol mulai kuis dan memilih tombol mulai dan sistem akan menampilkan tampilan kuis dan pengguna mengerjakan soal kuis. Setelah menjawab soal kuis maka sistem akan menampilkan skor kuis yang diperoleh pengguna, seperti pada gambar 4.

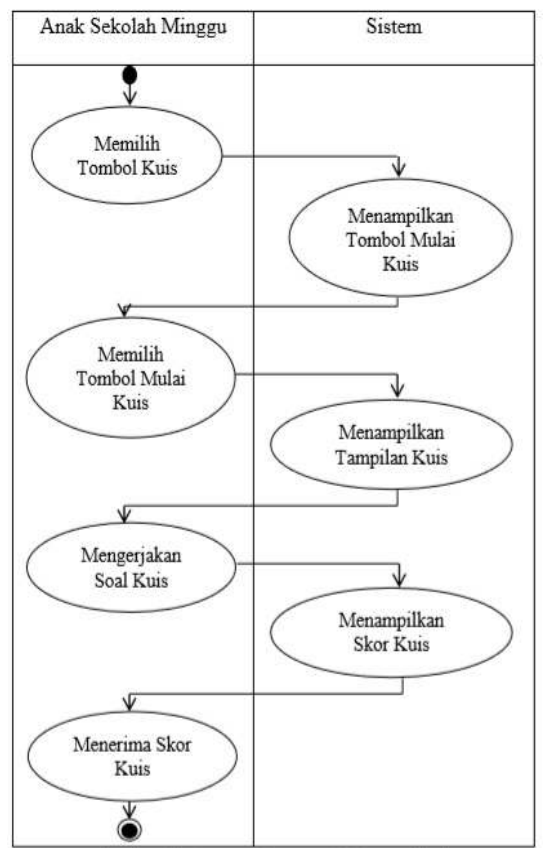

Gambar 4. Activity Diagram Kuis

d) Activity Diagram Halaman Lagu-Lagu

Anak Sekolah Minggu memilih halaman lagu-lagu kemudian sistem menampilkan daftar lagu. Setelah sistem menampilkan daftar lagu maka pengguna akan memilih judul lagu yang terdapat pada sistem, kemudian sistem menampilkan video lagu dan pengguna dapat mendengarkan lagu-lagu, seperti pada gambar 5 . 


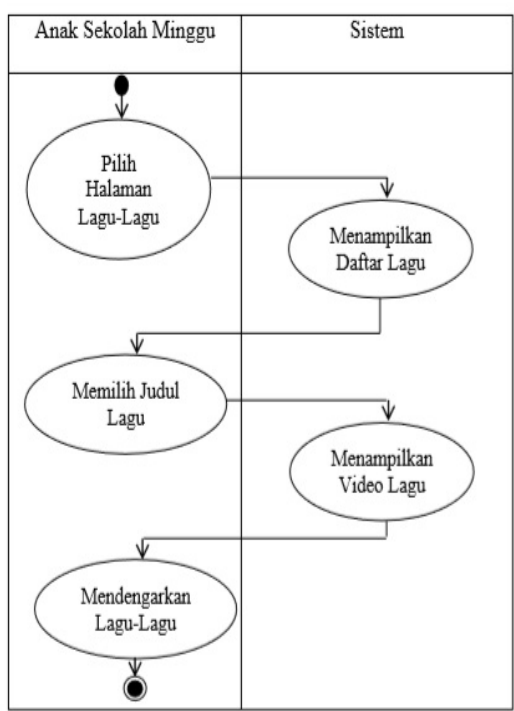

Gambar 5. Activity Diagram Halaman Lagu-Lagu

e) Activity Diagram Halaman Cerita Alkitab

Anak Sekolah Minggu memilih halaman cerita alkitab kemudian sistem menampilkan daftar cerita alkitab. Setelah sistem menampilkan daftar cerita alkitab maka Anak Sekolah Minggu dapat memilih judul cerita alkitab yang terdapat pada sistem, kemudian sistem menampilkan video cerita alkitab dan pengguna dapat mendengarkan cerita alkitab, seperti pada gambar 6 .

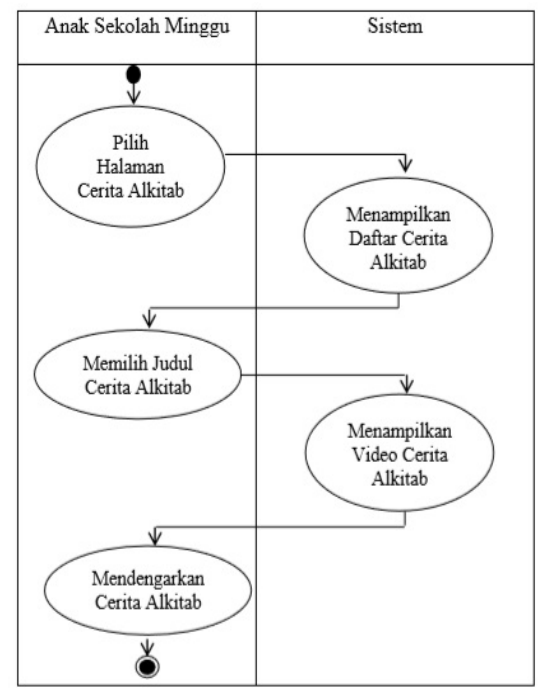

Gambar 6. Activity Diagram Halaman Cerita Alkitab

f) Activity Diagram Halaman Game Puzzle

Anak Sekolah Minggu memilih halaman game puzzle kemudian sistem menampilkan tampilan game puzzle. Setelah sistem menampilkan tampilan game puzzle maka Anak Sekolah Minggu dapat memilih potongan gambar, kemudian sistem menampilkan gambar yang dipilih dan Anak Sekolah Minggu menerima jawaban, seperti pada gambar 7 . 


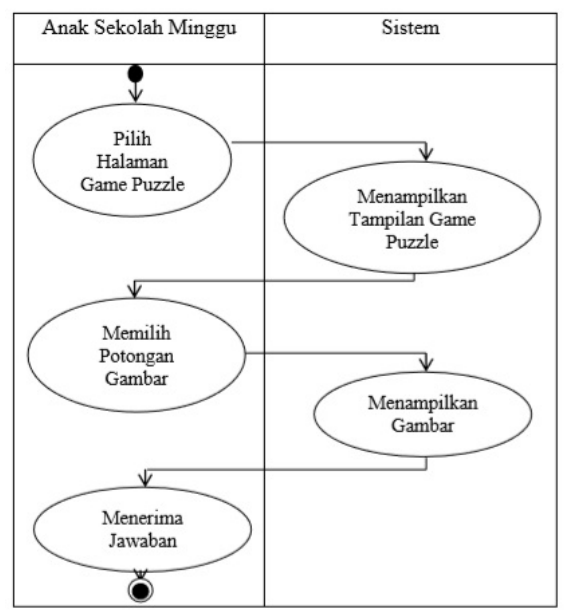

Gambar 7. Activity Diagram Halaman Game Puzzle

\section{3) Sequence Diagram}

a) Sequence Diagram Halaman Utama

Anak Sekolah Minggu masuk halaman utama media pembelajaran setelah itu sistem akan menampilkan halaman utama media pembelajaran pengguna memilih menu maka akan muncul halaman pilihan media pembelajaran pengguna inginkan, seperti pada gambar 8 .

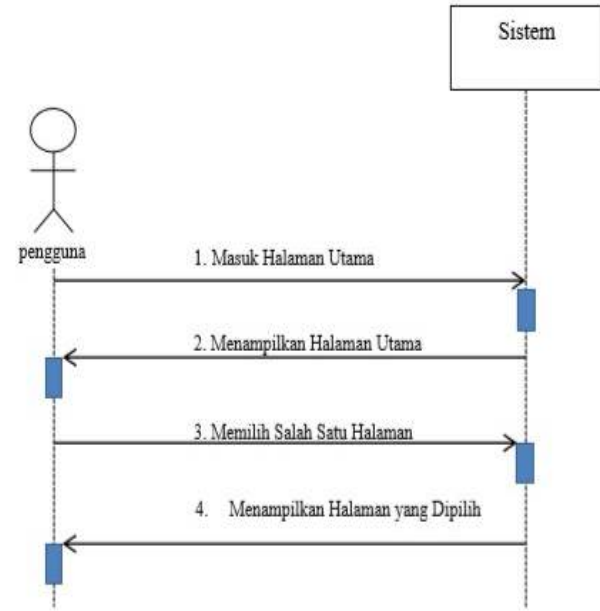

Gambar 8. Sequence Diagram Halaman Utama

b) Sequence Diagram Materi

Anak Sekolah Minggu masuk halaman materi setelah itu sistem akan menampilkan materi pada bulan juni, pada halaman materi bulan juni pengguna memilih salah halaman menu materi setelah itu sistem menampilkan materi yang akan dipelajari, seperti pada gambar 9 .

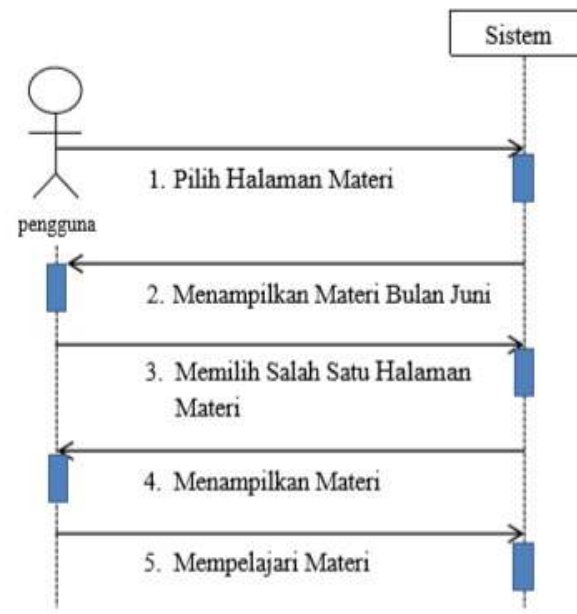

Gambar 9. Sequence Diagram Materi 
c) Sequence Diagram Kuis

Anak Sekolah Minggu memilih tombol kuis, sistem akan menampilkan tombol mulai kuis, pengguna memilih tombol mulai kuis, setelah itu sistem akan menampilkan tampilan kuis dan pengguna akan mengerjakan kuis dan akan mengetahui skor yang diperoleh setelah pengguna selesai mengerjakan kuis, seperti pada gambar 10 .

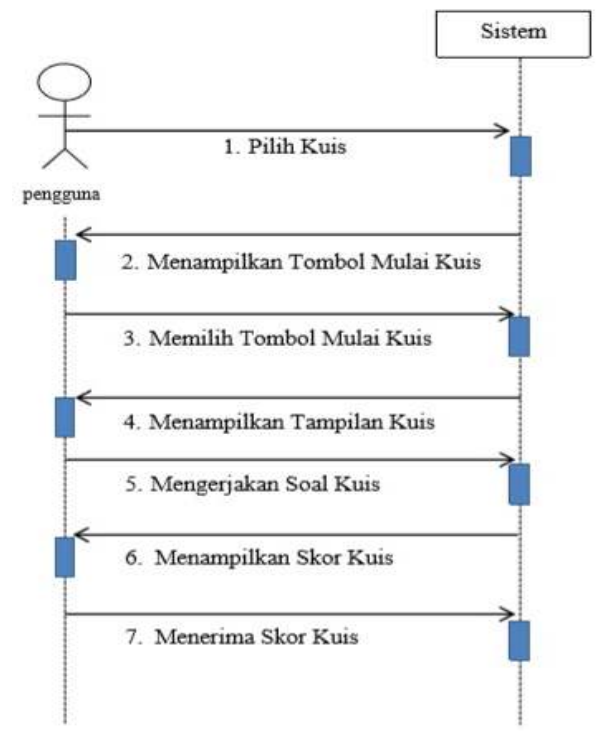

Gambar 10. Sequence Diagram Kuis

d) Sequence Diagram Lagu-Lagu

Anak Sekolah Minggu masuk halaman lagu-lagu setelah itu sistem menampilkan daftar lagu, pengguna dapat memilih judul lagu, kemudian sistem menampilkan video lagu yang didengarkan, seperti pada gambar 11.

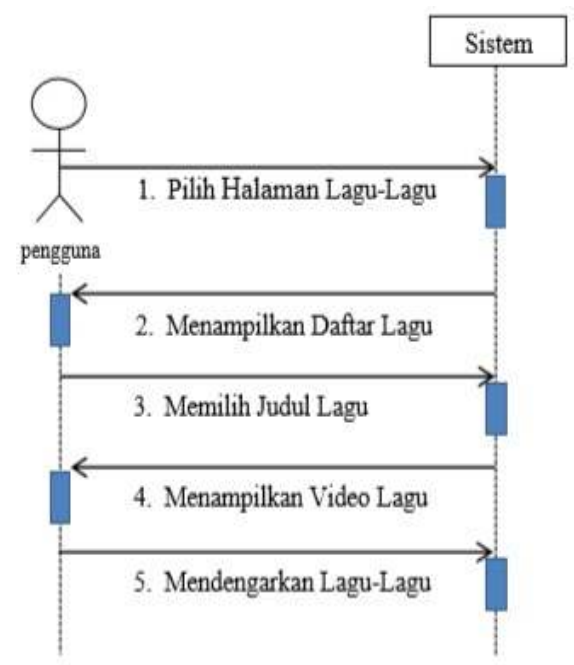

Gambar 11. Sequence Diagram Lagu-Lagu

e) Sequence Diagram Cerita Alkitab Anak Sekolah Minggu masuk halaman cerita alkitab setelah itu sistem menampilkan daftar cerita alkitab pengguna dapat memilih judul cerita alkitab, kemudian sistem menampilkan video cerita alkitab yang didengarkan, seperti pada gambar 12 . 


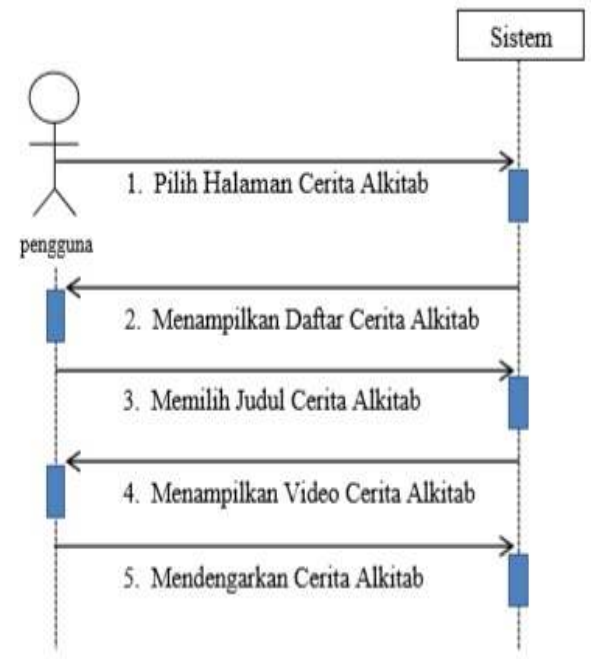

Gambar 12. Sequence Diagram Cerita Alkitab

f) Sequence Diagram Game Puzzle Anak Sekolah Minggu masuk halaman game puzzle setelah itu sistem menampilkan tampilan game puzzle dan pengguna dapat memilih potongan gambar kemudian sistem menampilkan gambar yang dipilih dan pengguna menerima jawaban, seperti pada gambar 13.

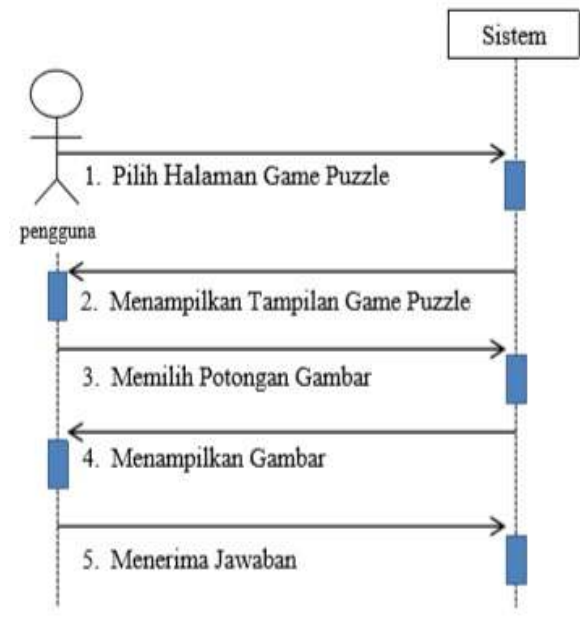

Gambar 13. Sequence Diagram Game Puzzle c. Pengumpulan Materi (Obtaining Content Material)

$$
\text { Merupakan }
$$

proses

pengumpulan segala sesuatu yang dibutuhkan dalam pembelajaran. Mengenai materi, kuis, lagu-lagu, dan cerita alkitab sekolah minggu yang akan disampaikan.

d. Penyusunan dan Pembuatan (Assembly)

Waktunya media diproduksi. Materi yang ditampilkan setiap minggunya berbeda karena di dalamnya terdapat sub kategori materi minggu ke 1 yaitu dengan judul Matius 4:18-22 Yesus memanggil murid-murid yang pertama, minggu ke 2 berjudul Ayub 1:1-5 Kesalehan Ayub dicoba, minggu ke 3 berjudul Galatia 6:1-10 Saling membantulah kamu, minggu ke 4 berjudul Matius 5:43-45 Yesus dan Hukum taurat, minggu ke 5 berjudul Lukas 17:11-19 serta filefile yang sudah didapat dirangkai dan disusun sesuai desain. Pada proses ini sangat dibutuhkan kemampuan dari ahli agar mendapat hasil yang baik dan pembuatan menggunakan Microsoft Powerpoint 2010 . 
e. Uji Coba (Testing)

Pengujian

program

dilakukan menggunakan Blackbox testing. Pengujian ini bertujuan untuk mengetahui adanya kesalahan-kesalahan yang ada pada sistem dan kemudian akan diperbaiki.

f. Menyebar Luaskan (Distribution) Media pembelajaran disimpan dalam media penyimpanan berupa Compact Disk (CD) atau Flashdisk. Setelah dilakukan penyimpanan, media pembelajaran didistribusikan ke guru sekolah minggu untuk dijadikan sebagai alat bantu mengajar dalam proses pembelajaran.

\section{HASIL DAN PEMBAHASAN}

Adapun hasil pada aplikasi Media Pembelajaran Interaktif yaitu:

a. Halaman Judul

Dalam halaman judul terdapat tombol mulai yang digunakan untuk membuka media pembelajaran, seperti pada gambar 14 .

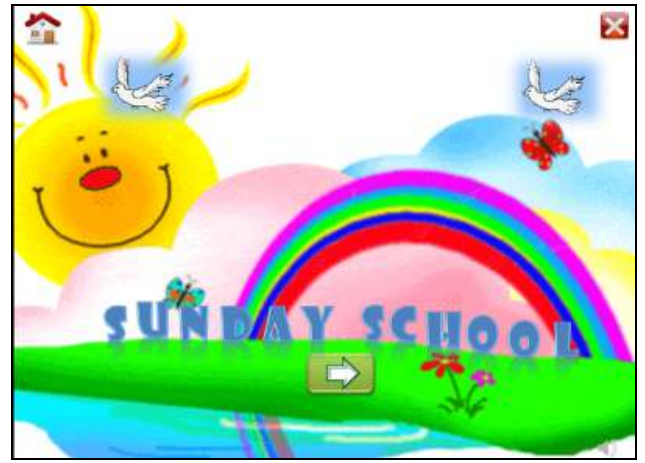

Gambar 14. Halaman Judul

b. Halaman Utama

Dalam halaman utama terdapat pilihan berbagai menu yang terdiri dari menu materi digunakan untuk membuka halaman materi pada bulan juni, menu lagu-lagu digunakan untuk membuka halaman daftar judul lagu-lagu sekolah minggu, menu cerita alkitab digunakan untuk membuka daftar judul cerita alkitab, dan menu game puzzle digunakan untuk membuka permainan menyusun gambar tokoh alkitab, seperti pada gambar 15 .

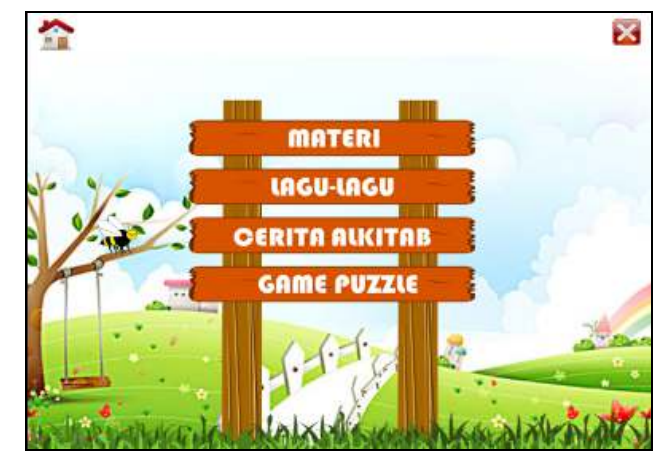

Gambar 15. Halaman Utama

c. Halaman Materi Bulan Juni

Dalam halaman materi bulan juni terdapat pilihan berbagai menu 
yang terdiri dari menu materi minggu ke 1 , menu materi minggu ke 2, menu materi minggu ke 3, menu materi minggu ke 4, dan menu materi minggu ke 5. Menu ini digunakan untuk membuka materi dalam waktu seminggu sekali, seperti pada gambar 16 .

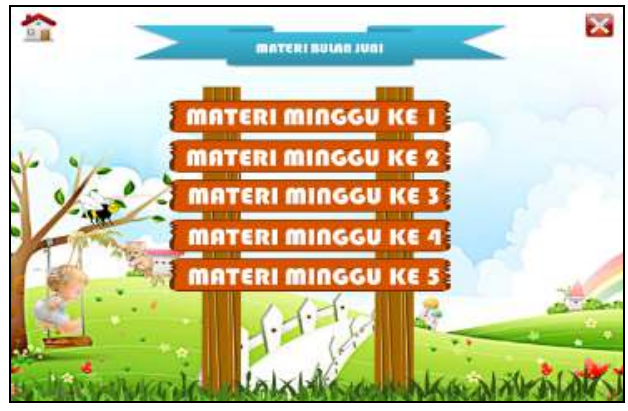

Gambar 16. Halaman Materi Bulan Juni

\section{d. Halaman Materi Minggu ke 1}

Dalam halaman materi minggu ke 1 terdapat materi yang dibuat meliputi isi kitab perjanjian lama dan perjanjian baru, serta terdapat tombol back, next, dan tombol kuis pada akhir materi, seperti pada gambar 17.

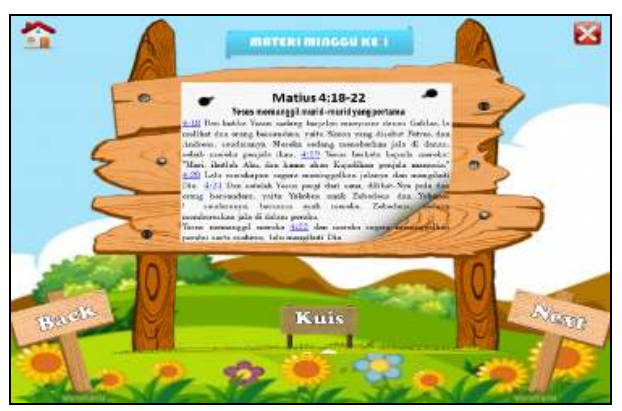

Gambar 17. Halaman Materi Minggu ke 1 e. Halaman Awal Mulai Kuis

Dalam halaman mulai kuis terdapat tombol mulai yang digunakan untuk membuka halaman kuis, seperti pada gambar 18 .

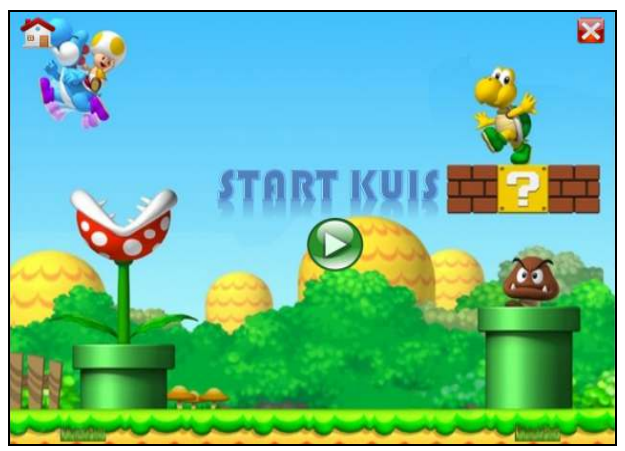

Gambar 18. Halaman Awal Mulai Kuis

f. Halaman Kuis

Halaman kuis digunakan pengguna untuk menjawab pertanyaan kuis dalam bentuk pilihan ganda dan jika pilihan jawaban dipilih maka ada keterangan disebelah kanan soal, apakah yakin dengan jawaban yang dipilih, jika yakin maka klik yes dan otomatis akan lanjut ke soal berikutnya dan terdapat tombol back untuk kembali ke soal sebelumnya jika pengguna ingin mengganti jawaban, seperti pada gambar 19. 


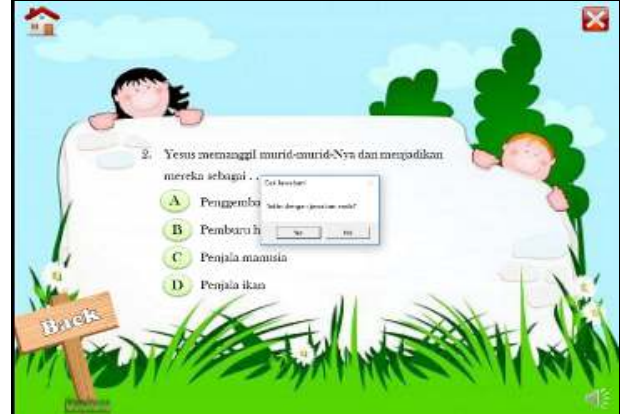

Gambar 19. Halaman Kuis

g. Halaman Skor

Halaman skor merupakan nilai yang didapat pengguna saat menyelesaikan kuis dan terdapat tombol ulangi kuis. Dan untuk skor yaitu diperoleh dari 1 soal bernilai 20, seperti pada gambar 20 .

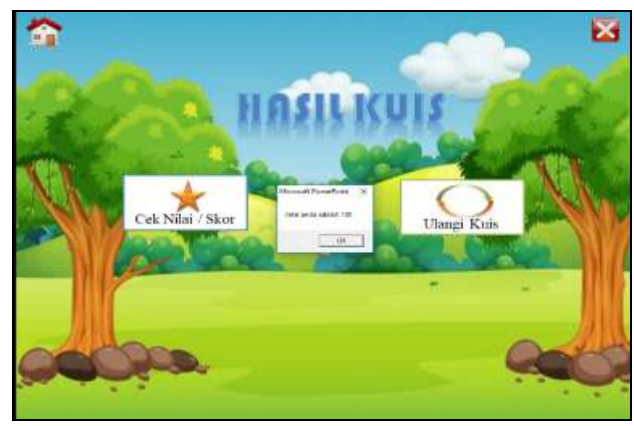

Gambar 20. Halaman Skor

h. Halaman Daftar Lagu-Lagu

Pada halaman ini terdapat judul lagu-lagu sekolah minggu yang dapat dipilih untuk membuka halaman lagu sekolah minggu, seperti pada gambar 21 .

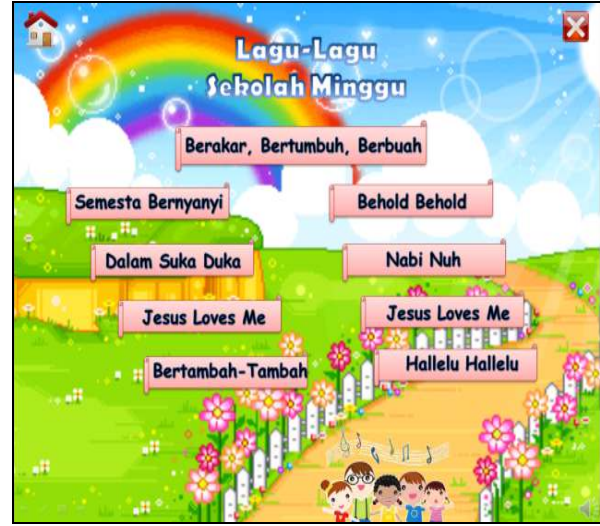

Gambar 21. Halaman Daftar LaguLagu

i. Halaman Lagu Sekolah Minggu

Halaman ini terdapat lagu sekolah minggu dalam bentuk video dan ada tombol back untuk kembali ke halaman daftar judul lagu, seperti pada gambar 22.

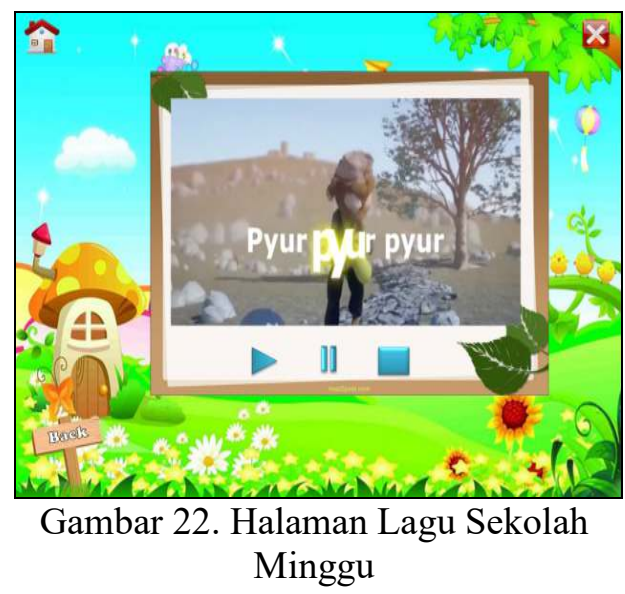

j. Halaman Daftar Cerita Alkitab

Pada halaman ini terdapat judul cerita alkitab yang dapat dipilih untuk membuka halaman cerita alkitab, seperti pada gambar 23. 


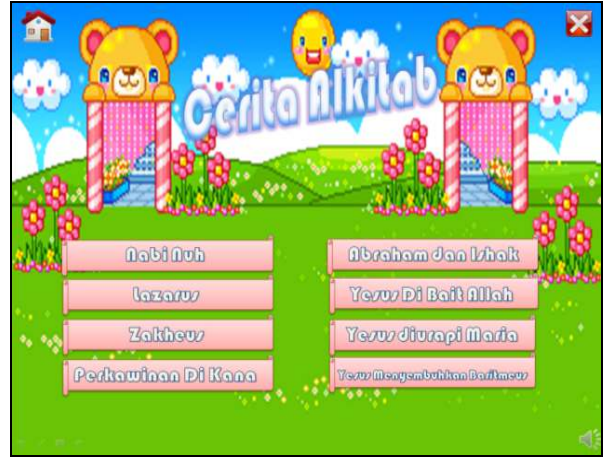

Gambar 23. Halaman Daftar Cerita Alkitab

k. Halaman Cerita Alkitab

Halaman ini terdapat cerita alkitab dalam bentuk video dan ada tombol back untuk kembali ke halaman daftar judul cerita alkitab, seperti pada gambar 24 .

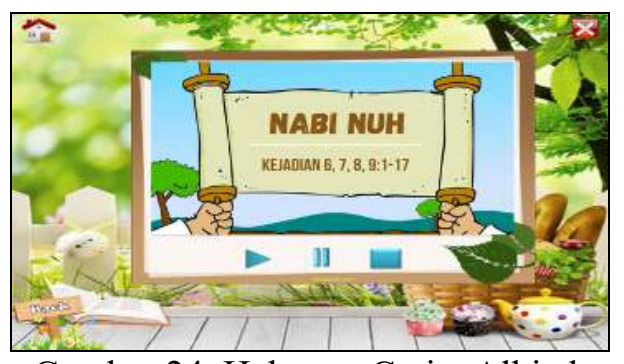

Gambar 24. Halaman Cerita Alkitab

1. Halaman Game Puzzle

Pada halaman game puzzle ini pengguna dapat memilih potongan gambar yang ada disebelah kanan untuk menebak gambar tokoh alkitab. Jika gambar terpasang dengan benar maka muncul jawaban dan tombol next untuk malanjutkan game selanjutnya, seperti pada gambar 25 .

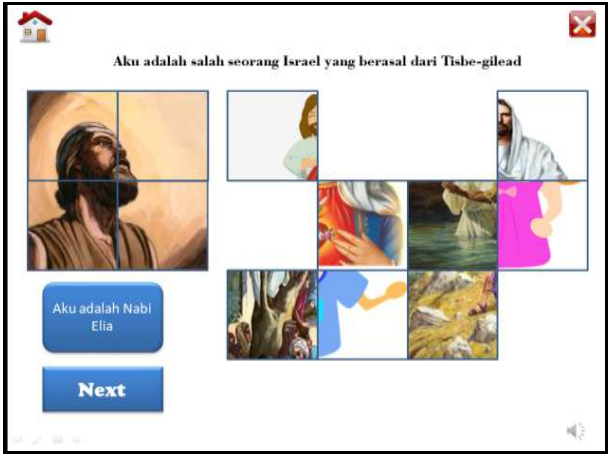

Gambar 25. Halaman Game Puzzle

Menurut (Sugiyono, 2015)

Perhitungan responden pada penelitian ini menggunakan Skala Likert untuk mengukur pendapat, dan persepsi seseorang tentang media pembelajaran ini. Jumlah data yang diminta untuk mengukur pendapat dan persepsi tersebut sebanyak 10 responden.

Dengan kriteria interpretasi presentase kelompok responden adalah sebagai berikut:

$$
\begin{array}{lll}
\text { Angka } 0 \%-20 \% & \text { Sangat Tidak } \\
& \text { Setuju (STS) } \\
\text { Angka } 21 \%-40 \% & \text { Tidak Setuju (TS) } \\
\text { Angka } 41 \%-60 \% & \text { Netral (N) } \\
\text { Angka } 61 \%-80 \%= & \text { Setuju (S) } \\
\text { Angka } 81 \%-100 \%= & \text { Sangat Setuju (SS) }
\end{array}
$$

Rumus untuk perhitungan hasil skor responden yaitu:

jumlah skor tiap pernyataan / jumlah skor tertinggi tiap pernyataan) x 100\%.

Maka berdasarkan perhitungan presentase kelompok responden tiap item pernyataan dapat diketahui seperti pada gambar tabel 26. 


\begin{tabular}{|c|l|c|c|}
\hline & \multicolumn{1}{|c|}{ Pernyataan } & Total Skor & $\begin{array}{c}\text { Perhitungan } \\
\text { Presentasi Kelompok } \\
\text { Responden }\end{array}$ \\
\cline { 3 - 4 } & Pernyataan & $\begin{array}{l}\text { Rumus : jumlah skor tiap } \\
\text { pernyataan / jumlah skor } \\
\text { tertinggi tiap } \\
\text { pernyataan) } \times 100 \%\end{array}$ \\
\hline 1 & $\begin{array}{l}\text { Media pembelajaran dapat } \\
\text { dijalankan. }\end{array}$ & 41 & $41 / 50 \times 100 \%=82 \%$ \\
\hline 2 & $\begin{array}{l}\text { Media pembelajaran tersebut } \\
\text { menarik untuk digunakan. }\end{array}$ & 43 & $43 / 50 \times 100 \%=82 \%$ \\
\hline 3 & $\begin{array}{l}\text { Media pembelajaran tersebut } \\
\text { dapat membantu proses } \\
\text { pembelajaran agama Kristen. }\end{array}$ & 43 & $43 / 50 \times 100 \%=86 \%$ \\
\hline 4 & $\begin{array}{l}\text { Media pembelajaran tersebut } \\
\text { akan bermanfaat bagi anak } \\
\text { sekolah minggu. }\end{array}$ & 44 & $44 / 50 \times 100 \%=86 \%$ \\
\hline 5 & $\begin{array}{l}\text { Media pembelajaran ini sudah } \\
\text { berjalan dengan baik. }\end{array}$ & 37 & $37 / 50 \times 100 \%=74 \%$ \\
\hline 6 & $\begin{array}{l}\text { Media pembelajaran sudah } \\
\text { baik dari segi warna. }\end{array}$ & 38 & $38 / 50 \times 100 \%=76 \%$ \\
\hline 7 & $\begin{array}{l}\text { Anak sekolah minggu } \\
\text { memahami materi yang } \\
\text { disampaikan dengan media. }\end{array}$ & 38 & $38 / 50 \times 100 \%=76 \%$ \\
\hline 8 & $\begin{array}{l}\text { Media dapat membangkitkan } \\
\text { motivasi anak sekolah } \\
\text { minggu. }\end{array}$ & 44 & $44 / 50 \times 100 \%=88 \%$ \\
\hline 9 & $\begin{array}{l}\text { Kuis sesuai dengan materi } \\
\text { yang telah dipelajari. }\end{array}$ & 40 & $40 / 50 \times 100 \%=80 \%$ \\
\hline
\end{tabular}

Gambar 26. Tabel Perhitungan Presentase Responden

Adapun untuk presentase kelompok responden secara keseluruhan:

Total skor keseluruhan / jumlah skor tertinggi keseluruhan $100 \%=362 /(50$ x 9) $x 100 \%=80,4 \%$

Maka presentase kelompok responden secara keseluruhan adalah $80,4 \%$ yang berarti tergolong sangat baik. Adapun presentase kelompok responden untuk secara keseluruhan merujuk pada gambar 27.

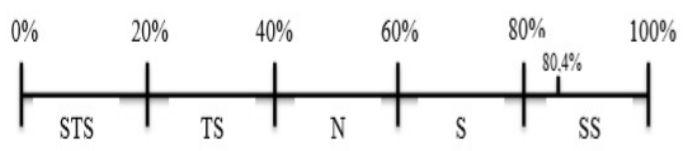

Gambar 27. Hasil responden 80,4 \%

Dari skala di atas dapat diketahui bahwa hasil dari perhitungan kuesioner yang dinilai dari 10 responden dari 9 pernyataan maka diperoleh interpretasi sebesar $80,4 \%$ responden menyatakan bahwa mereka sangat setuju jika Media Pembelajaran Interaktif dapat digunakan dengan baik untuk anak sekolah minggu.

\section{KESIMPULAN}

Dalam pembahasan telah diuraikan dari dapat diambil kesimpulan yaitu media pembelajaran ini bertujuan menghasilkan sarana media pembelajaran interaktif untuk anak sekolah minggu yang dapat menambah minat serta motivasi belajar. Berdasarkan hasil dari uji coba tahapantahapan media dengan menggunakan metode Black Box Testing dapat disimpulkan bahwa program telah diuji serta sesuai dengan harapan yang telah ditentukan dan layak dipergunakan. Dan berdasarkan tanggapan pengguna terhadap Media Pembelajaran Interaktif adalah sebesar $80,4 \%$ dari hasil tersebut maka tanggapan semua responden adalah sangat setuju, karena 80,4\% ini berada dimana dalam kriteria skor tanggapan tersebut kriterianya adalah sangat setuju.

\section{DAFTAR PUSTAKA}

Abdillah \& Jogiyanto, Willy. (2015). Partial Least Square (PLS), 

Alternatif Structural Equation Modeling (SEM) dalam Penelitian Bisnis.

Anamara, M. G. V., 2014. Evaluasi Program Implementasi Standar PAUD. Jurnal Pendidikan Usia Dini, 8(2), 301-314.

Darmawan, I P. Ayub., 2015. Dasardasar Menga- jar Sekolah Minggu. Ungaran: Sekolah Tinggi Teologi Simpson.

Denissa A. L., 2018. Pengembangan Media Video Animasi Untuk Materi Pembelajaran Karakter Bersaksi Di Sekolah Minggu, Jurnal Pendidikan Agama Kristen Vol. IV, No. I.

Mamangkey, et al., 2013. Aplikasi EVisual AID Sekolah Minggu Berbasis Android. Manado: SESINDO.

Mustika, Eka P. A. S., Maissy P., 2017. Pengembangan Media Pembelajaran Interaktif dengan Menggunakan Metode Multimedia Development Life Cycle. Jurnal Online Informatika. Vol. 2. No. 2.

Nora, 2018. Pengaruh Penggunaan Alat Peraga Terhadap Peningkatan Motivasi Belajar Firman Tuhan Pada Anak Sekolah Minggu Di GKKK Makassar Pos PI Panakkukang, thesis, Sekolah Tinggi Theologia Jaffray.

Pressman. 2015. Rekayasa Perangkat Lunak: Pendekatan Praktisi Buku I. Andi Yogyakarta.

Riniwati, 2020. Pembinaan Guru Sekolah Minggu Untuk Mengajarkan Konsep
Keselamatan Pada Anak, Jurnal Teologi Injili dan Pembinaan Warga Jemaat, Vol. 4, No. 2, Juli 2020: 186-194

Sugiyono, 2015. Statistik Nonparametris untuk Penelitian. Bandung: Alfabeta. 